sases, similar results can be obtained by prrogallic and 3alicylic acids, which are selective remedies affecting only the diseased tissues, and commonly used by dermatologists in the treatment of lupus vulgaris. With reference to the sisaltaneous application of heliotherapeutic measures advoated by Mr. Gauvain, it may be mentioned that the late Frofessor Finsen of Copenhagen employed pyrogallic acid tintment to a large extent in combination with the light treatment which bears his name, and it was doubtless to the association of these two methods that he owed, in no small Jyegree, his success in extensive cases of cutaneous tuberovilosis.

I am, Sir, yours faithfully,

Brarley-street, W., April 7th, 1919. S. FRNEST DORE.

\section{THE FUTURE OF THE TUBERCULOSIS PROBLEM.}

To the Editor of THE LANCET.

STHA, - I fear that Mr. P. C. Tarrier-Jones, in his paper on the above subject in your issue of March 22nd, is inclined to take a somewhat one-sided view of this matter. There are more ways than one of approaching this problem. It is possible, as $\mathrm{Mr}$. Varrier-Jones suggests, to attempt to segregate cases after they have become more or less advanced hich may be inferred from the stress he lays on treating these people for long periods in colonies, or, on the other hand, we may after much delay begin to treat early cases at sanatoriums before appreciable destruction of tissue has taken place. Anyone of experience knows that early cases freated at properly conducted sanatoriums do not necessarily oreak down speedily. Indeed, a forecast of the length of time required to treat any given case can be made from a consideration of the length of time the patient has been allowed to go about doing his work before being sent to a sanatorium. Treating all early cases is not only treating individuals, but is a means of saving whole families from becoming victims of this disease.

Mr. Varrier-Jones seems to have fallen into error when he states: "Our energies should be concentrated not so completely on the symptoms of the diseased-those who have well-defined symrtoms and signs, in whom the lung tissue has broken down and by whom the bacilli are freely expectorated." The whole point of $\mathrm{my}$ contention is that symptoms which are quite easily noticed are often prominent months before the lungs are sufficiently injured to permit of a diagnosis being made by physical examination. We are at the parting of the ways, and have got to decide now whether we are going to follow the advice of Sir James Mackenzie who has well stated his case in a recent number of the \$yectator) and treat patients at a time when it is worth while, or continue to treat them when they are past cure. We might use as our motto a saying of Shakespeare :-

A little fire is quickly trodden out; Which being suffered, rivers cannot quench.

Fis applies equally to the individual and the community. I am, Sir, yours faithfully,

EDWARD E. PREST.

A \$rshire Sanatorium, New Cumnock, March 24th, 1919.

\section{SACCHAROSE INJECTIONS IN PULMONARY PHTHISIS.}

To the Editor of THE LANCET.

SIrR,-In reply to Mr. J. Lavens West's letter in your issue 04 March 29th, the British Mellical Journal of July 15th, 1918, p. 671 , contains a note on this treatment, introduced ty Professor Lo Monaco. The method consists of giving $5 \mathrm{~g}$. set saccharose (cane sugar) in $5 \mathrm{c.cm}$. of sterilised distilled water daily, in one or two intramuscular in jections. It is claimed that after three or four days the temperature falls, night-sweats cease, cough is very much lessened, and the mount of expectoration is greatly diminished. The method is still $s u b$ judice. - I am, Sir, yours faithfully,

HENRY CuRTIS, F.R.C.S.,

Consulting Surgeon, National Sanatorium

\#larley-street, W., April 5th. Association, London.

4. * At a meeting of the Société de Thérapeutique held in 3aris on Jan. 8th Dr. G. Rosenthal commented on Rénon and Mignot's recent communication, in which they stated that injections of saccharose had no action either on human tuberculosis or on the experimental disease in the guinea-pig f $s$ de The LANCE', March 15th, p. 424). This objection was only applicable to hypodermic injections, which, as Rosenthal had shown in a previous paper, did not possess much value. On the other hand, a dailv intravenous injec tion of 5-20 c.cm. of Lo Monaco's solution (equal parts o saccharose and water) constituted an efficacious treatment in states of malnutrition, and indirectly had a favourable action on tuberculosis. The improvement was usually rapid, being well marked after 10-15 days' treatment. - ED. L.

\section{WOMEN CHIEHS:}

\section{To the Editor of THE LANCET.}

Sin,-Di. W. C. Rivers will, I hope, forgive me for diagnosing his complaint as acute salicism. No doubt many women doctors are unsuited to command their male colleagues, but is this sufficient reason for excluding the few, whose administrative gifts are patent, from high appointments? We all know the stenophrenic male, with the mentality of a monkey and the spitefulness of an eunuch. Many of us also know the gifted woman with vision, tact, and administrative genius. If Dr. Rivers finds these types on the medical siaff of a municipality does he suggest promotion of the former at the expense of the latter? And would he, courteously but firmly, tell the woman-

$$
\begin{aligned}
& \text { "Though you are too weak to journey } \\
& \text { Up the mountain steep and high, } \\
& \text { You can stand within the valley } \\
& \text { While the multitudes go by"? }
\end{aligned}
$$

April 7th, 1919.

I am, Sir, yours faithfully, Cla Ude Lilhivgstor.

\section{URBAN VITAL STATISTICS.}

(Woek onded April 5th, 1919.)

English and Welsh Towns.-In the 96 English and Welsh towns, with an aggregate civil population estimated at $16,500,000$ persons, th annual rate of mortality, which had steadily declined from $35 \cdot 7$ to $19 \cdot 3$ in the five preceding weeks, further fell to 17.9 per 1000 . In London. with a population slightly exceeding $4,000,000$ persons, the annual death-rate was $17 \cdot 1$, or 0.5 per 1000 below that recorded in the previou week; among the remaining towns the rates ranged from 8.3 in Glllingham, $9 \cdot 2$ in Wast Ham. and 10.0 in Tynemouth, to 30.3 in Grimsby, $30 \cdot 9$ in Great Yarmouth, $33 \cdot 3$ in Hastings, and 34.5 in Middlesbrough. The principal epidemic diseases caused 1000 , and included 73 from ineasles, 40 from whooplng-cough 34 from diphtheria, 29 from infaatile diarrhoea, 14 from scarlet $2 \cdot 1$ in Sheffield, 7.3 in Rotherham, Measles caused a death-rate of $2 \cdot 1$ in Sheffield, 7.3 in Rotherham, and 8.7 in Middlesbrough ; and whooping-cough of 27 in stoke-on-Trent. The deaths attributed to influenza, which had declined from 3889 to 888 in the five preceding weeks, further fell to 569, and included 91 in London, 56 in Bir mingham, 34 in Manchester, 30 in Liverpnol, and 27 in Sheffield There were 6 cases of small-pox, 103 of scar.et fever, and 1158 of diphtheria under treatment in the Metropolitan Asylums Hospitals and the London Fever Hospital, against 6,1027 , and 1163 respec. tively at the end of the previous week. The causes of 45 death in the 96 towns were uncertified, of which 8

Scotch Towns-In the 16 largest Scotch towns, with an aggregate population estimated at nearly $2,500,000$ persons, the annual rate of mortality, which had declined from $40^{\circ} 0$ to $20^{\circ} 5$ in the five preceding weese. further fell to 18.5 per 1000 . The deaths from influenza numbered 10 , while in 59 deaths classified as due to other conditions influenza was a contributory cause; in the previous week these numbers were 14 and 88 respectively. The $4: 9$ deaths in Glasgow corresponded to an annual rate of 19.5 per 1000 , and included 35 from whooping-cough, 9 from measles, 6 from infantile diarrhoea, and 5 from diphtheria. The 108 deaths in Fdinburgh were equal to a rate of 16.7 per 1000 and included 10 from whooping-cough, 3 from diphtheria, and 1 from measles.

Irish Towns.-The 253 deaths in Dublin corresponded to an annua ate of $32 \cdot 6$, or $1 \cdot 1$ per 1000 above that recorded in the previous week, and included 41 from influenza, 4 from infantile diarrboea. and 1 each from measles, whooping-cough, and diphtheria. The 168 a fatal case of infantils diarrhoea.

VITAL STATISTICS OF LONDON DURING THE YEAR 1918.

In the accompanying table statistics of sickness and mortality in the City of London and in each of the metropolitan boroughs are summarised for the 5 ear 1918. With regard to the notified cases of infectious diseases, it appears that the number of persons reported to be suffering from one or other of the ten diseases specified in the table was equal to a rate of $4 \cdot 4$ per 1000 of the population, estimated a $4,026.901$ persons; in the three preceding years the rates were $7 \cdot 1,6 \cdot 1$, and 4.2 per 1000 respectively. Among the various boroughs the rate last year ranged from 2.4 in the City of Westminster, $2 \cdot 5$ in Chelses 27 in Hampstead, 28 in the City of London, $3 \cdot 1$ in Kensington, 33 in Hammersmith, 3.3 in St. Marylebone, and 3.4 in Holborn, to 5.2 in Greenwich, 6.2 in Stepney, 6.3 in Bermondsey, 7.3 in Bethnal Green, and 8.0 in Southwark. Thirty-five cases of small-pox were notified last year against 11, 1 , and 0 in the three preceding years; of these, 24 cases belonged to Stepney. The prevalerice of scarlet fever was about 12 per cent. more than in the preceding year; 6811 cases were notiffed, against 8756 and 6110 in the two precedin vears. Among the metro- 